\title{
ブリストル大学 化学教室
}

松 浦 幸 仁*

\section{1.イギリスの都市 ブリストルについて}

ブリストルはロンドンから西方約 $200 \mathrm{~km}$ に位置する港 湾・工業都市である. 約 40 万人の人々が居住するイング ランド西部の中核都市であり, 数多くの製造業が基点を置 く. 特に, エアバス社が大工場を有し, 超音速航空機のコ ンコルドが生産された地であることは有名である。また， フォードやホンダの大集積基地があり，ヨーロッパの物流 の中心として栄えている. ブリストルの北東方向には, 日 本人にも人気のあるコッッウオルズの牧歌的な風景が広が り, 南方にはストーンヘンジなどの観光地がある.ささらに は，ブリストルはイングランド内で最西端に位置し，西方 のブリストル海峡に掛かる橋を越えると，連合王国内で自 治が認められているウエールズに達する. ウエールズ内で は公共機関の案内表示や道路標識などで英語とウエールズ 語が併記されており, 独自の文化や習慣が今も守られてい るので，イングランドとは異なる異国情緒を味わうことが できる.

ブリストルの街は, おおむね安全であり, Center と呼 ばれる街の中心は休日になると大勢の買い物客でにぎわう。 Center 北辺には Downs と呼ばれる広大な芝生の公園と䦥 静な住宅街が続いており, 豊かな緑に囲まれたきれいな街 である．ただし，他のヨーロッパ先進国の例に漏れず物価 は総じて高めであり, 特に家賃は家族 4 人で生活できるア パートを借りるのに，ポスドクの給料の大半を費やす必要 がある。もっとも，大学にポスドクなどで赴任する場合は， 大学の宿泊施設を利用すれば若干安くあげることはできる。 ブリストルの食に関しては, フィッシュ\&チップス，イン グリッシュブレックファスト，アフターヌーンティーなど イギリスの伝統的な料理を味わうことができるほかは，旧 植民地から引き継がれたインド料理や中華料理など世界中 の料理を堪能することができる. ブリストルには日本料理 店らしきレストランもあるので興味のある方は扔試しあれ。 また，ブリストル周辺は昔からリンゴ酒（Cider）の産地 として有名である。このリンゴ酒はリンゴを発酵させて造 られるアルコールで, 日本で売られている甘味料を加えた シードルとは異なり, 若干醳母の味と匂いが残り, 好きに

\footnotetext{
* Matsuura, Yukihito

大阪市立工業研究所 電子材料課

大阪市城東区森之宮 1-6-50（广536-8553） 2006.12.25 受理
}

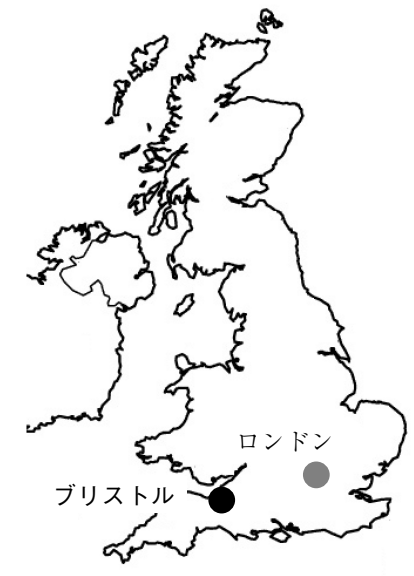

図 1 イギリス地図

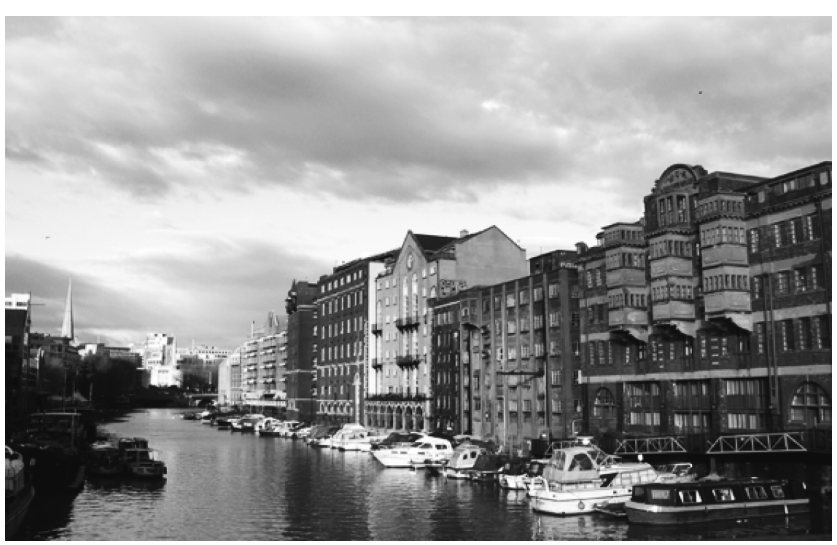

図 2 ブリストルの運河

なったらビールよりもこちらのほうが良いという人もたく さんいる.

\section{2. ブリストル大学について}

街には，ブリストル大学と西イングランド大学の二つの 総合大学とブリストル市立大学などのカレッジがあり, 多 くの学生が世界中から集まる.ブリストル大学は, 1876 年に設立された University College of Bristol を前身とし て，1909年に設立されており，イギリスで初めて女性の 入学を認めた開明的な大学である。ノーベル賞受賞者を多 数輩出し, 理論物理学者のポール・ディラック,物性物理学 


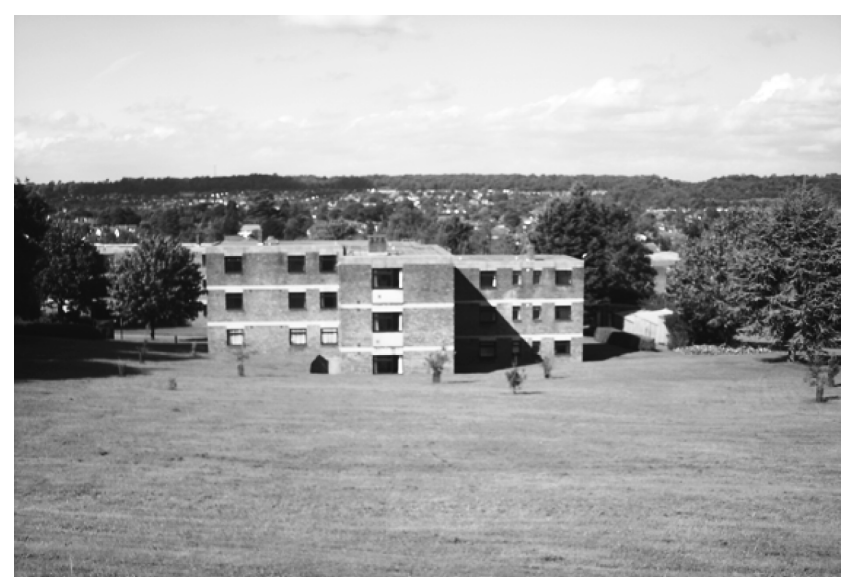

図 3 ブリストル大学の学生寮

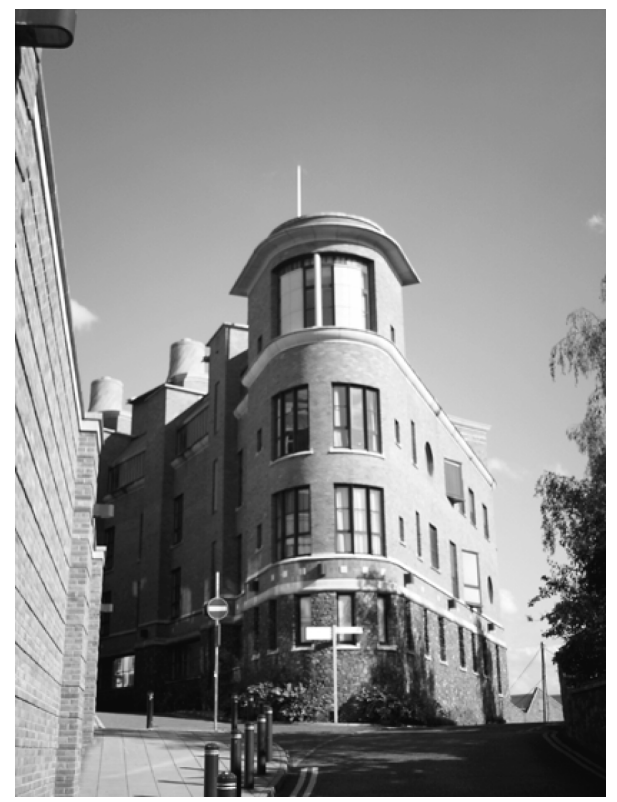

図 4 ブリストル大学化学教室

者のネイビル・モット，希ガスを発見した化学者ウイリア ム・ラムゼー, X 線回折により生体物質の分子構造を解明 した女性化学者のドロシー・ホジキンなどが卒業生である. 学生は約 10,000 人, 大学院生は 2,500 人在学しており, 海 外からの留学生の比率は $10 \%$ を超えている国際的な総合 大学である. 広大な敷地に学生寮が充実しており, しかも海 外からの留学生が優先的に入寮できるので, 学生には好評 を得ている. 学部は, 法学部, 芸術学部, 理学部, 医学部, 工 学部, 社会学部からなり, Times 社の調查では 2006 年度 において，イギリスの大学では 10 位の高評価を得ている.

\section{3. ブリストル大学化学教室について}

理学部化学教室は, 有機化学・生化学科, 物理化学・理 論化学科, 物質化学・材料化学科の 3 学科からなる. NMR 測定, マス・スペクトル測定およびX線構造解析などの 化学分析, さらには, 試薬やガラス器具などの供給, ガラ ス細工, 溶媒の精製などにも専門スタッフが常駐し, 学生 が研究に専念できる環境が整えられている。私が所属した 物質化学・材料化学科には, 研究スタッフがテーマごとに

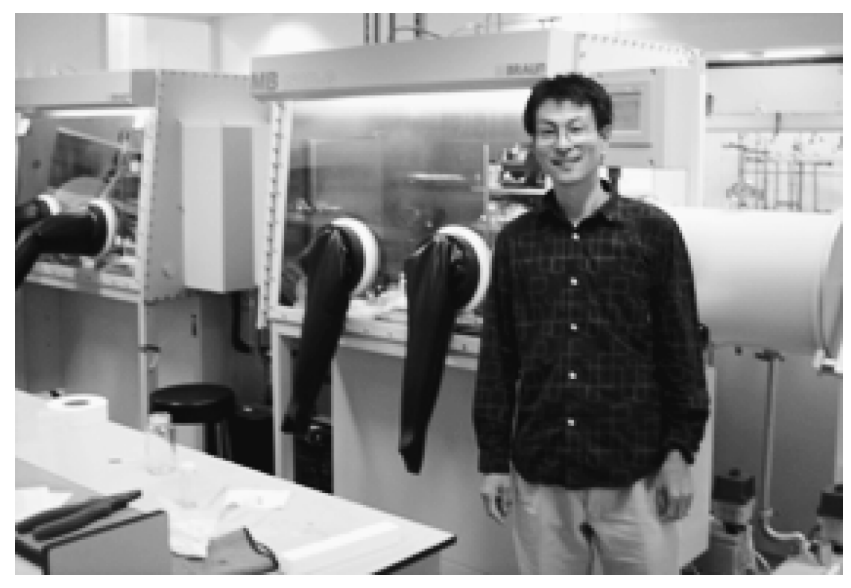

図 5 実験室内にて

結びついて，有機金属化学，配位化学，物質化学，典型元 素化学, 構造化学などのグループを形成している. テーマ により，スタッフが各グループに重複して所属する場合も あり，専門テーマの垣根を越えた共同研究が行われている。 私が所属したイアン・マナーズ教授の研究グループは, 教授がカナダ・トロント大学より 2005 年 9 月に移籍して 作られた新しい研究グループである. マナーズ教授は, フェ ロセンを骨格にもつ有機金属ポリマーの合成と物性の研究 で世界的に著名な化学者である. 研究室には, 助手が 1 名 と 20 人のポスドクおよび大学院生が在籍している. その 研究内容は, ポリマーの研究に留まらず, 電子・半導体メー カーとの共同研究により, 電子材料への応用研究も盛んに 行っている. 具体的には, フェロセンがシリコン原子など の架橋により歪んだ構造をもつフェロセノファンを合成し， それに熱, 光または触媒などを加えることにより，フェロ セン同士がシリコン原子で架橋したポリマーを合成する手 法を開発してきた。このポリマーは鉄原子間に強い相互作 用のあることが確認されており，ヨウ素などをドーピング することにより導電性が上昇することが確認されている. また，このポリマーを燒結することにより, 強磁性を带び たセラミックスを作製することに成功している，さらには， この焼結体はカーボンナノチューブの前駆体になることも 確認されている. 最近では, このポリマーと(メタ)アクリ ルとのブロック共重合体を合成し, 自己組織化の手法を用 いてナノ構造体を形成している. 応用研究としては, この ポリマーを带電防止や磁気シールドに応用したり, 電子線 レジスト材料への応用を検討したりしている．上記フェロ センポリマー以外には，主鎖がリン原子と窒素原子からな るポリフォスファゼンなどの合成を手掛けている。このポ リマーは耐熱性が高く, 難燃性物質として期待されている.

\section{4. 最 後に}

ブリストル大学はロンドンから遠方にあり, しかもオック スフォードやケンブリッジほど著名でないのにも関わらず, 他学部の学生を合わせて 10 名程度の日本人が在籍してい る.化学教室では, 年に $1 \sim 2$ 名程度の日本人留学生が在籍 している.特に, 高分子や材料化学の分野では, 日本の大学 の先生方との幅広い交流があるので, 今後も多くの日本人 研究者が訪れて盛んに共同研究が行われることを期待する. 